\title{
Expression of class II major histocompatibility complex antigens on alveolar epithelium in interstitial lung disease: relevance to pathogenesis of idiopathic pulmonary fibrosis
}

\author{
C G M KALLENBERG,* B M SCHILIZZI,* F BEAUMONT,† L DE LEIJ,* \\ S POPPEMA, $\ddagger$ T H THE*
}

From the Departments of ${ }^{*}$ Clinical Immunology, $\nmid$ Pulmonology, and $\ddagger$ Pathology, University Hospital, Groningen, The Netherlands

SUMMARY To determine whether expression of class II major histocompatibility complex antigens on alveolar epithelium is relevant to the pathogenesis of idiopathic pulmonary fibrosis (IPF) lung biopsy specimens were investigated from nine patients with IPF with or without connective tissue disease, four patients with sarcoidosis, eight patients with lung disease of presumably infectious origin, and five controls. The alveolar epithelium stained strongly with anti-Ia (HLA-DR) or Leu 10 (HLA-DS) monoclonal antibodies, in eight of nine biopsy specimens from patients with IPF, in three of four biopsy specimens from patients with sarcoidosis, in all six biopsy specimens from patients with presumably viral, mycobacterial, or pneumocystic lung disease, but not in control lung tissue, nor in two biopsy specimens from patients with bacterial pneumonia.

Mononuclear cell infiltrates consisted of T4 positive (helper/inducer) lymphocytes, predominantly present in a nodular arrangement in the interstitium, and T8 positive (cytotoxic/suppressor) cells, distributed equally in the interstitium and subepithelially or intraepithelially. T8 cells outnumbered T4 cells in six of nine biopsy specimens from patients with IPF, but in none of the biopsy specimens from patients with sarcoidosis or interstitial lung disease of infectious origin.

Although the expression of class II antigens on the alveolar epithelium which is infiltrated by T8 cells in IPF is consistent with local presentation of autoantigens and an ensuing local immune response, class II expression is also present in interstitial lung disease of sarcoidosis and microbial infections: its role in the pathogenesis of IPF must therefore remain speculative.

Recent data on the pathophysiological mechanisms of idiopathic pulmonary fibrosis (IPF) indicate activation of macrophages and polymorphonuclear leucocytes, resulting in tissue damage and fibrosis. ${ }^{1}$ The initiating events leading to the accumulation of activated mononuclear cells in the lung interstitium are not, however, fully understood. There is some evidence that autoimmune mechanisms have a role in the pathogenesis of IPF: serum autoantibodies to nuclear antigens are often detected in IPF. ${ }^{23}$ In addition, pulmonary disease in connective tissue illnesses such as scleroderma, rheumatoid arthritis, and systemic lupus

Accepted for publication 27 November 1986 erythematosus (SLE), is, in many cases, indistinguishable histologically from that which occurs in IPF. The accumulation of mononuclear cells in the interstitial spaces in close contact with the alveolar epithelium, observed in IPF with and without connective tissue disease, might suggest that the supposed autoimmune response is directed against structural antigens of the alveoli. The prerequisites for the induction of such an autoaggressive reaction are as yet unknown.

In organ specific autoimmune diseases such as Hashimoto's thyroiditis, primary biliary cirrhosis, and type I diabetes mellitus expression of class II MHC antigens on the epithelial cells-for example, HLA-DR and other antigens-has been shown 
recently. ${ }^{4-6}$ It has been postulated that class II expression on these cells might be an important initial or additional event by which the presentation of the relevant autoantigens to autoreactive $T$ helper cells could lead to an effective autoimmune response. ${ }^{78}$ Epithelial cells functioning as antigen presenting cells are also able to produce another signal necessary for the induction of an immune response-namely, interleukin-1, as shown recently for epidermal cells. ${ }^{9}$ Normal epithelial cells do not express class II antigens, and as such, are, not capable of presenting autoantigens.

For this reason we investigated whether the prerequisites for local presentation of autoantigens might also be present on the alveolar epithelium in IPF. We described previously in a preliminary communication the expression of class II antigens on the alveolar epithelium in some patients with IPF with or without connective tissue disease, ${ }^{10}$ and suggested that alveolar epithelial cells may function as autoantigen presenting cells in IPF. In the present study we investigated whether expression of class II MHCantigens on the alveolar epithelium is, indeed, a specific finding in IPF, which may underly the induction of an autoimmune response directed against structural alveolar antigens. Thus we studied the expression of class II antigens on epithelial cells in lung biopsy specimens from patients with IPF, sarcoidosis, viral, and bacterial infections. In addition, we studied the distribution and localisation of lymphocyte subsets in these specimens to evaluate whether the immunohistological findings were compatible with the hypothesis of local presentation of autoantigens to the immune system.

\section{Patients and methods}

We studied lung biopsy specimens from nine patients with pulmonary fibrosis (five with and four without a connective tissue disease; cases 1-9), four patients with sarcoidosis (cases 10-13), six immunocompromised patients with interstitial pneumonitis probably related to viral, mycobacterial, or pneumocystis infections (cases 14-19), and two patients with bacterial pneumonitis (cases 20 and 21 ). Tables 1-3 give the clinical data of the patients. Normal lung tissue was obtained during thoracotomy for lung carcinoma in five patients. A diagnosis of IPF was based on: (i) a lung biopsy specimen showing interstitial fibrosis with inflammatory changes and without granulomas; (ii) interstitial markings on chest $x$-ray; (iii) a restrictive ventilatory disorder by pulmonary function testing; (iv) no history of exposure to materials that are related to the development of interstitial lung disease. The diagnosis of rheumatoid arthritis, SLE, and systemic sclerosis was based on the criteria of the American Rheumatism Association. Connective tissue disease was diagnosed on the presence of antibodies to nucleoribonucleoprotein in association with clinical features of SLE and systemic sclerosis. A diagnosis of sarcoidosis was based on: (i) a lung biopsy specimen with non-caseating epitheloid granulomas; (ii) no evidence of mycobacterial or fungal infections; (iii) no history of exposure to materials that are related to the development of granulomatous lung disease.

LUNG BIOPSY SPECIMENS

A $3 \times 3 \mathrm{~cm}$ biopsy specimen was obtained from the

Table 1 Clinical data and data from bronchoalveolar lavage in nine patients with pulmonary fibrosis at time of lung biopsy

\begin{tabular}{|c|c|c|c|c|c|c|c|c|}
\hline \multirow[b]{2}{*}{ Case No } & \multirow[b]{2}{*}{$\begin{array}{l}\text { Age (year) } \\
\text { and sex }\end{array}$} & \multirow{2}{*}{$\begin{array}{l}\text { Duration of } \\
\text { pulmonary } \\
\text { symptoms } \\
\text { (year) }\end{array}$} & \multirow{2}{*}{$\begin{array}{l}\text { Chest } x \text {-ray } \\
\text { (interstitial } \\
\text { markings) }\end{array}$} & \multicolumn{3}{|c|}{ Bronchoalveolar lavage } & \multirow[b]{2}{*}{ Diagnosis* } & \multirow[b]{2}{*}{ Treatment } \\
\hline & & & & $\begin{array}{l}\text { Total cell } \\
\text { No }\left(\times 10^{6}\right)\end{array}$ & $\begin{array}{l}\% \text { of } \\
\text { neutrophils }\end{array}$ & $\begin{array}{l}\% \text { of } \\
\text { lymphocytes }\end{array}$ & & \\
\hline 1 & $46 / F$ & $0 \cdot 3$ & ++ & $31 \cdot 3$ & 53 & 3 & $\begin{array}{l}\text { Systemic } \\
\text { sclerosis }\end{array}$ & None \\
\hline $\begin{array}{l}2 \\
3\end{array}$ & $\begin{array}{l}43 / F \\
43 / F\end{array}$ & $\begin{array}{l}0 \cdot 3 \\
0 \cdot 3\end{array}$ & $\frac{ \pm}{t}+$ & $\begin{array}{l}21 \cdot 0 \\
15 \cdot 0\end{array}$ & $\begin{array}{r}0 \\
12\end{array}$ & $\begin{array}{l}11 \\
27\end{array}$ & $\begin{array}{l}\text { SLE } \\
\text { UCTD }\end{array}$ & $\begin{array}{l}\text { None } \\
\text { Prednisone } \\
(45 \mathrm{mg} / \mathrm{d})\end{array}$ \\
\hline $\begin{array}{l}4 \\
5 \\
6 \\
7\end{array}$ & $\begin{array}{l}57 / \mathrm{M} \\
66 / \mathrm{M} \\
51 / \mathrm{M} \\
56 / \mathrm{F}\end{array}$ & $\begin{array}{l}0 \cdot 6 \\
8 \\
3 \\
0 \cdot 2\end{array}$ & $\begin{array}{l}++t \\
++ \\
+ \\
++\end{array}$ & $\begin{array}{l}37 \cdot 6 \\
22 \cdot 9 \\
18 \cdot 3 \\
20 \cdot 0\end{array}$ & $\begin{array}{r}8 \\
6 \\
1 \\
13\end{array}$ & $\begin{array}{r}20 \\
71 \\
5 \\
35\end{array}$ & $\begin{array}{l}\text { IPF } \\
\text { IPF } \\
\text { IPF } \\
\text { UCTD }\end{array}$ & $\begin{array}{l}\text { None } \\
\text { None } \\
\text { None } \\
\text { Prednisone } \\
\quad(10 \mathrm{mg} / \mathrm{d})\end{array}$ \\
\hline $\begin{array}{l}8 \\
9 \\
\end{array}$ & $\begin{array}{l}58 / \mathrm{M} \\
50 / \mathrm{M}\end{array}$ & $\begin{array}{l}0 \cdot 9 \\
4\end{array}$ & $\begin{array}{l}t+ \\
t+t\end{array}$ & $\begin{array}{l}38 \cdot 7 \\
13 \cdot 2\end{array}$ & $\begin{array}{r}77 \\
2\end{array}$ & $\begin{array}{r}3 \\
12\end{array}$ & $\begin{array}{l}\mathbf{R A} \\
\mathbf{R A}\end{array}$ & $\begin{array}{l}\text { NSAID } \\
\text { D-penicillamine }\end{array}$ \\
\hline $\begin{array}{l}\text { Controls } \\
\qquad(n=9)\end{array}$ & $32 \cdot 6(12 \cdot 4)$ & & & $11 \cdot 1(3 \cdot 7)$ & $1(2)$ & $9(6)$ & & \\
\hline
\end{tabular}

* Coding: SLE, systemic lupus erythematosus; UCTD, undefined connective tissue disease; IPF, idiopathic pulmonary fibrosis;

RA, rheumatoid arthritis.

Case 3: Raynaud's phenomenon, arthralgia, IgM rheumatoid factor, interstitial lung disease.

Case 7: Raynaud's phenomenon, discoid lupus, arthralgia, fever, rheumatoid factor, interstitial lung disease. 
Expression of class II MHC antigens in interstitial lung disease

Table 2 Clinical data and data from bronchoalveolar lavage in four patients with sarcoidosis

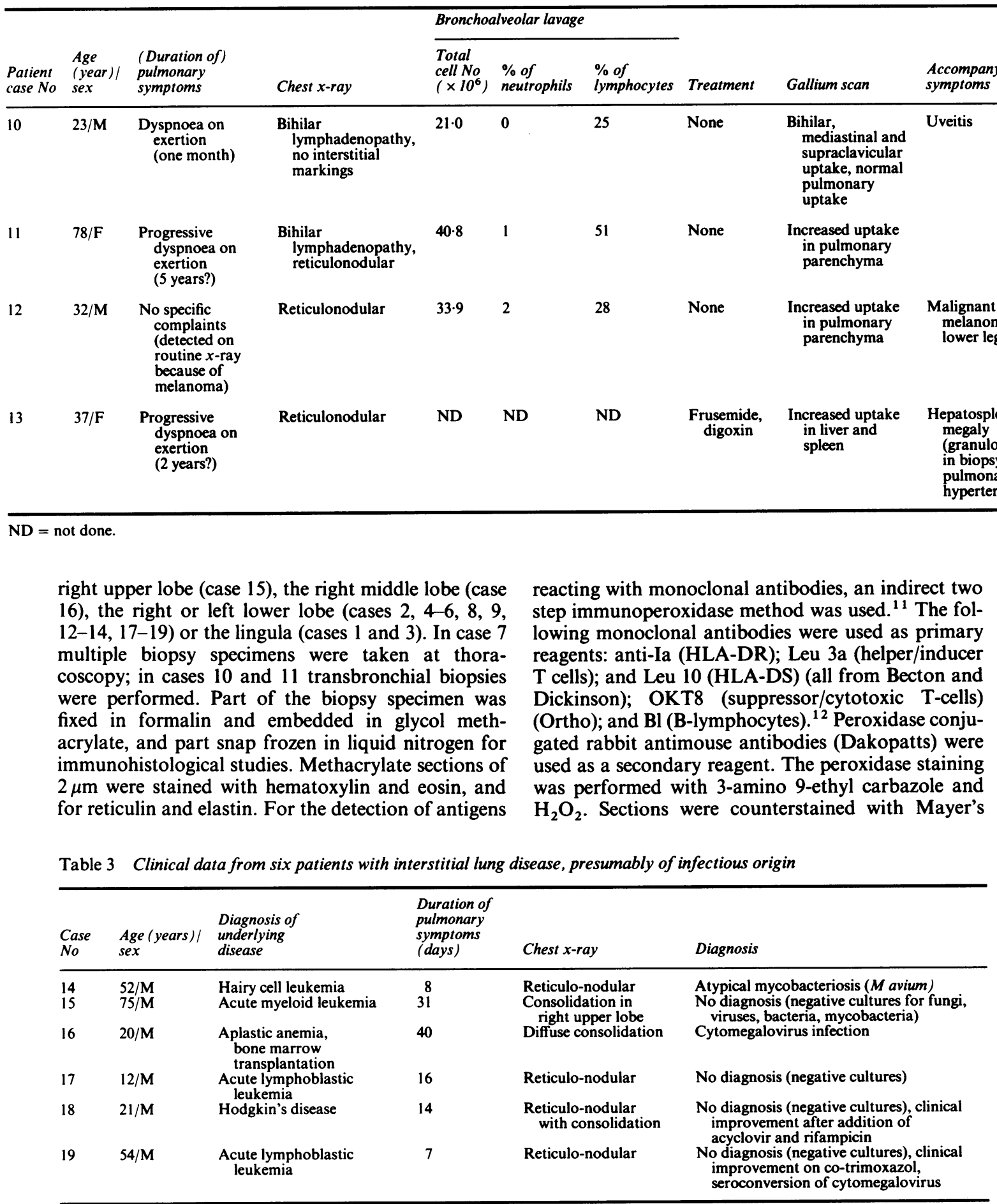


hematoxylin, evaluated by two independent observers, and scored semiquantitatively.

\section{Results}

\section{HISTOPATHOLOGY}

Lung specimens from nine patients with IPF with or without a connective tissue disease (table 1) showed infiltration with mononuclear cells in the interstitium and fibrosis in all cases. In three patients (cases 5, 8, and 9) lymphocytic infiltrates were, in part, present in a follicular arrangement (fig 1). Two of these patients (cases 8 and 9) had rheumatoid arthritis. Table 4 summarises these data. Lung specimens from four patients with sarcoidosis (table 2) showed mononuclear cell infiltration. In the cases 10 and 11 a few granulomas were present, but fibrosis and Langhans' giant cells were not detected. In cases 12 and 13 fibrosis and many giant cell granulomas were present.

In the biopsy specimens from six immunocompromised patients with interstitial lung disease of acute or subacute onset (table 3 ) mononuclear cells were invariably present in the interstitium. In addition, plasma cells were present in five of six biopsy specimens. In cases 17-19 infiltration of polymorphonuclear cells was also observed. Two of these patients were diagnosed as having atypical mycobacterial infection (case 14) or cytomegalovirus infection (case 16), whereas in the remaining cases a diagnosis of viral infection was assumed but not substantiated (table 3 ). In all these biopsy specimens cuboid metaplasia of the alveolar epithelium was present to a greater or lesser extent; but fibrosis was absent (cases 14-17) or present to a very limited amount (cases 18 and 19).

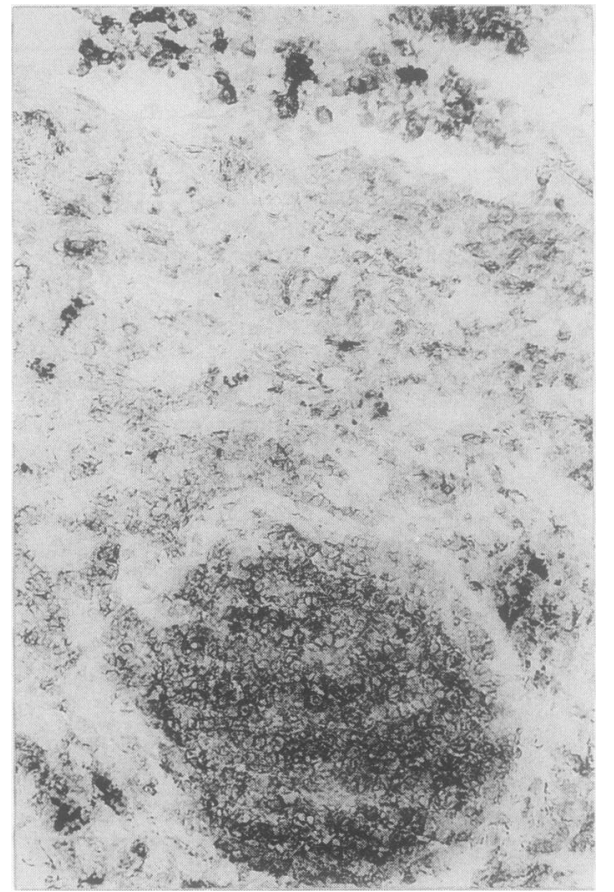

Fig 1 Immunoperoxidase staining with Leu 10 in cryostat section of lung from patient with rheumatoid arthritis. Lymphocyte infiltration is seen in follicular arrangement.

In the two patients with bacterial pneumonia there was a heavy exudate of polymorphonuclear leucocytes, and mononuclear cell infiltration was not present.

Table 4 Immunohistological findings in lung biopsy specimens of nine patients with IPF with and without connective tissue disease, and of five controls

\begin{tabular}{|c|c|c|c|c|c|c|c|c|c|c|}
\hline & \multicolumn{9}{|c|}{ Case No } & \multirow{2}{*}{$\begin{array}{l}\text { Controls } \\
(n=5)\end{array}$} \\
\hline & $l$ & 2 & 3 & 4 & 5 & 6 & 7 & 8 & 9 & \\
\hline $\begin{array}{l}\text { Mononuclear cell infiltration } \\
\text { Interstitial fibrosis }\end{array}$ & $\begin{array}{l}++ \\
+\end{array}$ & $\begin{array}{l}+ \\
+\end{array}$ & $\begin{array}{l}++ \\
+t\end{array}$ & $\begin{array}{l}+t+ \\
+t\end{array}$ & $\begin{array}{l}++t \\
+\end{array}$ & $\begin{array}{l}++ \\
+\end{array}$ & $\begin{array}{l}++ \\
+\end{array}$ & $\begin{array}{l}++t \\
++\end{array}$ & $\begin{array}{l}+++ \\
++\end{array}$ & $\begin{array}{l}\text { Absent } \\
\text { Absent }\end{array}$ \\
\hline Ia staining of bronchial epithelium & $+t+$ & $+t$ & $+t+$ & ++ & $++t$ & + & $+t+$ & + & + & \pm \\
\hline Ia staining of alveolar epithelium & + & \pm & ++ & ++ & ++ & + & +++ & + & + & - \\
\hline $\begin{array}{l}\text { Leu } 10 \text { (DS)-staining of bronchial } \\
\text { epithelium }\end{array}$ & - & - & + & + & $+t$ & + & + & ND & ND & - \\
\hline $\begin{array}{l}\text { Leu } 10 \text { (DS)-staining of alveolar } \\
\text { epithelium }\end{array}$ & + & - & - & + & - & - & + & ND & ND & - \\
\hline $\begin{array}{l}\text { T4 positive lymphocytes } \\
\text { T8 positive lymphocytes } \\
\text { Bl positive lymphocytes }\end{array}$ & $\begin{array}{l}+t \\
+t \\
+\end{array}$ & $\begin{array}{l}- \\
\pm\end{array}$ & $\begin{array}{l}+t \\
+t \\
\text { ND }\end{array}$ & $\begin{array}{l}++ \\
++t \\
\text { ND }\end{array}$ & $\begin{array}{l}++ \\
++ \\
++\end{array}$ & $\begin{array}{l}+ \\
+t \\
\pm\end{array}$ & $\begin{array}{l}+ \\
++ \\
\pm\end{array}$ & $\begin{array}{l}t \\
+t \\
t+t\end{array}$ & $\begin{array}{l}+ \\
+t \\
+t+\end{array}$ & $\begin{array}{l}\text { Absent } \\
\text { Absent } \\
\text { Absent }\end{array}$ \\
\hline
\end{tabular}

ND $=$ not done 


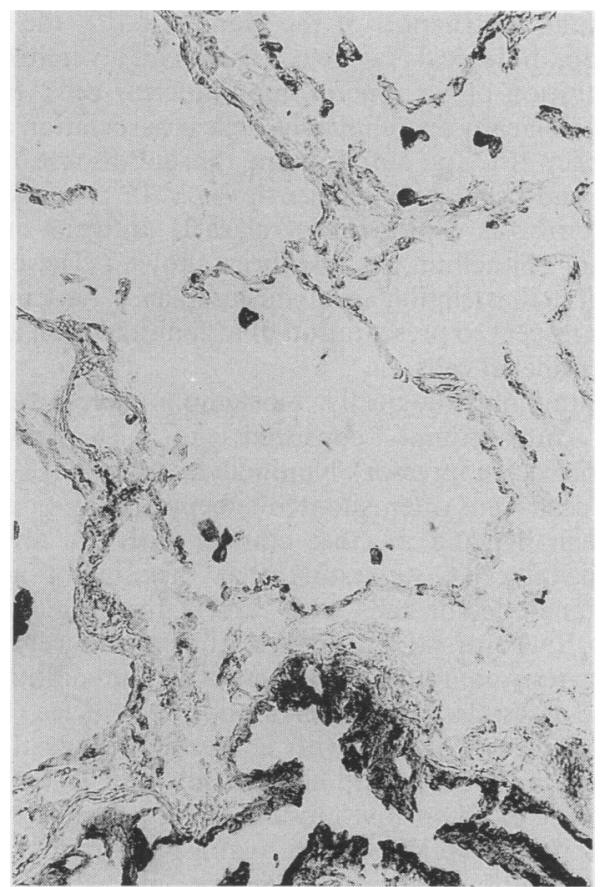

Fig 2 Immunoperoxidase staining of control lung tissue showing negative staining for $H L A-D R$. Bronchial epithelium and scattered alveolar macrophages are positive.

macrophages were strongly positive in all five specimens, and the vascular endothelium was positive in two of the biopsy specimens. Using Leu 10 monoclonal antibody to detect the expression of HLA-DS, we found only some scattered mononuclear cells to be positive (fig 3 ).

In the patients with IPF with or without connective tissue disease, bronchial epithelium was strongly positive for Ia-antigens. In all nine cases the alveolar epithelium was also positive (fig 4), although weakly in case 2. Expression of HLA-DS, detected by staining with Leu 10, was observed on the bronchial epithelium in five of seven cases, and on the alveolar epithelium in two cases (fig 5).

In sarcoidosis strongly positive Ia staining of the bronchial epithelium was present in all four cases (fig 6). The alveolar epithelium stained positive in three cases. HLA-DS was detected on the bronchial epithelium of only one patient. The alveolar epithelium was negative for HLA-DS in all four cases (table 5).

Intense expression of Ia-antigens on both bronchial and alveolar epithelium was also detected in the biopsy specimens from six immunocompromised patients with interstitial lung disease caused by Mycobacterium avium infection (case 14), cyto- megalovirus infection (case 16), or a possible viral infection (cases 15, 17-19). Ia expression, however, was not present on the alveolar epithelium from two patients with bacterial pneumonia (fig 7). Tables 4-6 summarise these data.

\section{MONONUCLEAR CELL INFILTRATION}

In all cases with IPF with or without connective tissue disease, lymphocyte infiltration was present in the interstitium. T8 positive cells outnumbered $T 4$ cells in six of these nine biopsy specimens. In the remaining specimens the number of $\mathrm{T} 4$ cells equalled that of $\mathrm{T} 8$ cells. $T$ cells were distributed both diffusely and in a nodular arrangement. T4 cells predominated in these nodules (fig 8); T8 cells were more equally distributed in the interstitium. Often T8 cells were localised subepithelially or intraepithelially, and, in some cases, also in the alveoli (fig 9). Seven out of the nine biopsy specimens with mononuclear cell infiltration were stained with anti-Bl monoclonal antibody to detect B lymphocytes. B cells were found in relatively small numbers compared with $\mathrm{T}$ cells, with the exception of the biopsy specimens from three patients (two with rheumatoid arthritis-cases 8 and 9, and one patient with IPF, case 5). In these biopsy specimens the lym-

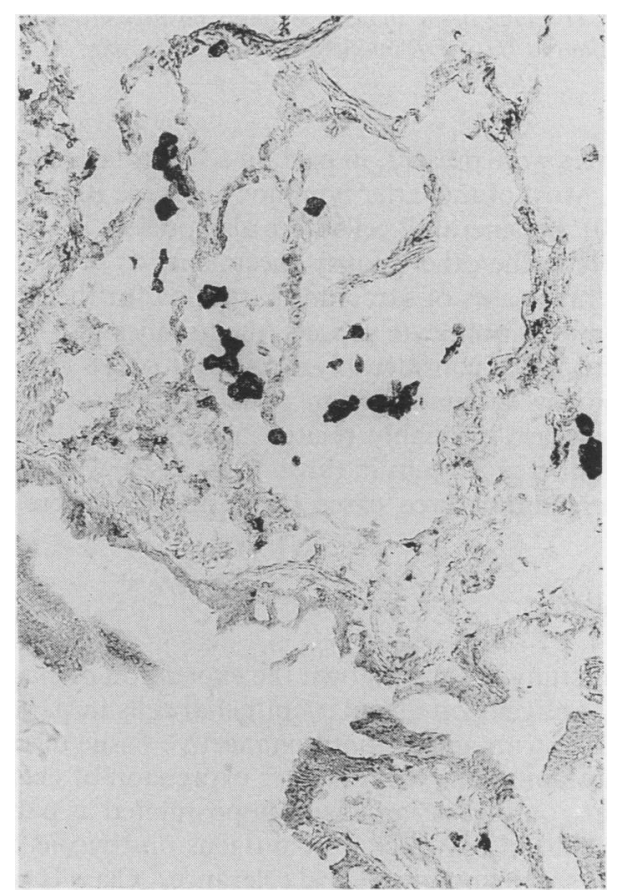

Fig 3 Control lung biopsy tissue showing weak immunoperoxidase staining of bronchial epithelium and negative staining of alveolar epithelium to Leu 10. Scattered alveolar macrophages are seen with positive staining. 


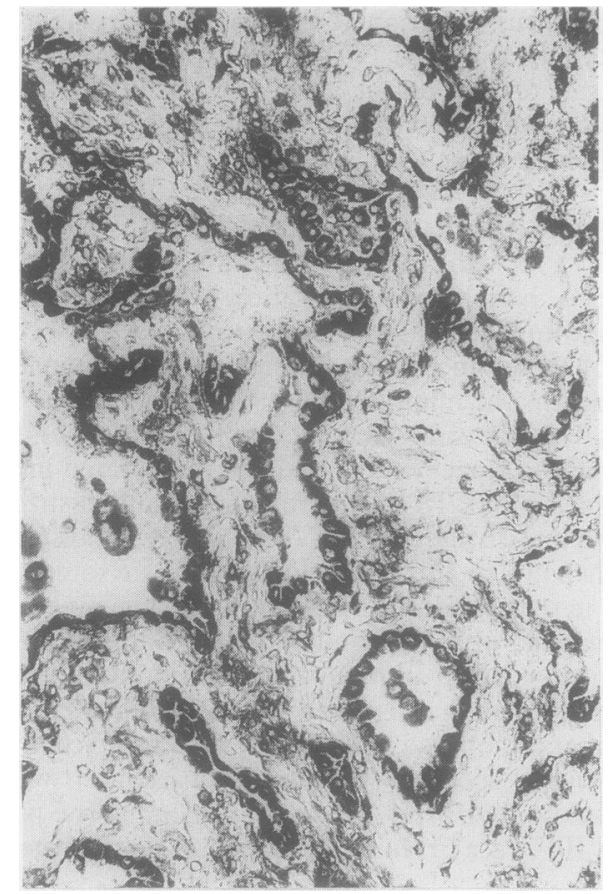

Fig 4 IPF lung tissue showing strongly positive alveolar epithelium to HLA-DR immunoperoxidase staining.

phocytes were present, in part, in a follicular arrangement. Most of the latter lymphocytes were $\mathrm{Bl}$ positive (fig 10). In general, B cells were also present in (small) clusters in the other biopsy specimens.

In three cases of sarcoidosis, studied for the distribution of lymphocyte subsets, the number of T4 cells did not differ considerably from that of T8 cells. In the biopsy specimens from patients with interstitial lung disease, probably related to infection, T4 cells outnumbered T8 cells in three of six cases, whereas in the remaining three cases these numbers were the same.

\section{Discussion}

In this study we have shown the expression of class II MHC antigens on alveolar epithelial cells in patients with IPF with and without connective tissue disease. In autoimmune thyroid disease expression of class II antigens on thyrocytes has been postulated as part of a mechanism by which autoantigens on thyroid cells might escape immunological tolerance. ${ }^{7}$ Class II positive thyroid cells have been shown to function as antigen presenting cells in vitro. ${ }^{8}$ Thus these cells might present their autoantigens in the context of class II antigens to sensitised lymphocytes, resulting in auto-
Kallenberg, Schilizzi, Beaumont, de Leij, Poppema, The

immune destruction of the gland. In IPF the main histopathological feature consists of an alveolitis with infiltration of, in general, mononuclear cells. Histopathologically and clinically, a clear association exists between IPF and autoimmune thyroid disease,,$^{13}$ and IPF and primary biliary cirrhosis. ${ }^{14}$ In primary biliary cirrhosis expression of class II antigens on the biliary epithelium has also been shown. ${ }^{5}$ These data suggest that similar mechanisms play a part in IPF with respect to presentation of autoantigens on alveolar epithelial cells.

Immunohistologically, most mononuclear cells in the interstitium consisted of T8 positive (cytotoxic/suppressor) lymphocytes. These T8 positive cells were often situated subepithelially or intraepithelially, and in close contact with the alveolar epithelial cells, suggesting that they might act as immune effector cells with respect to alveolar antigens. In contrast, T4 positive (helper/inducer) lymphocytes were found in clusters in the interstitium, in some cases also within B lymphocyte follicles. These observations concord with immunohistological data from a recent study on six patients with IPF. ${ }^{15}$ The presence of T4 positive clusters and B lymphocyte follicles in the interstitium is, again, in favour of local induction of an (auto)immune response, which might

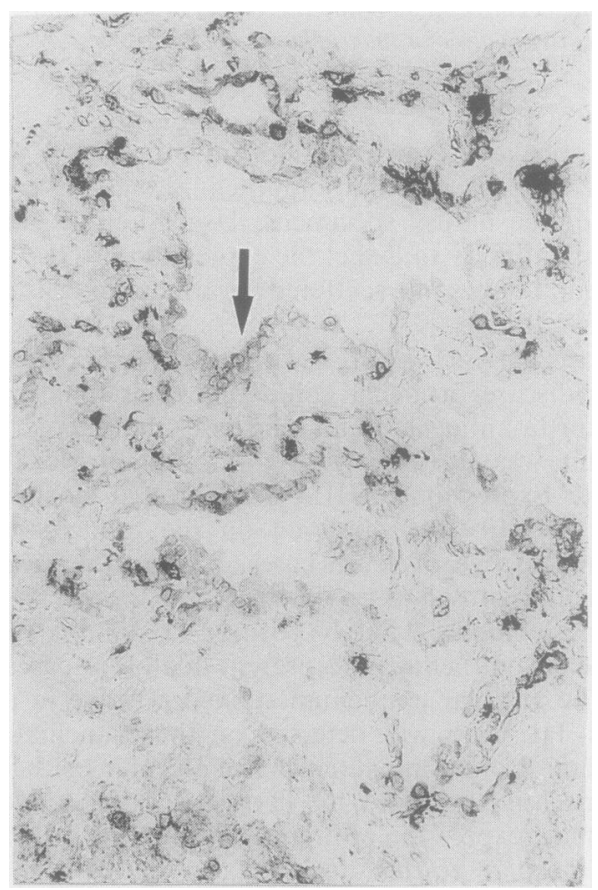

Fig 5 Immunoperoxidase staining of IPF lung tissue showing weakly positive staining of alveolar epithelium to Leu 10 (arrow). 


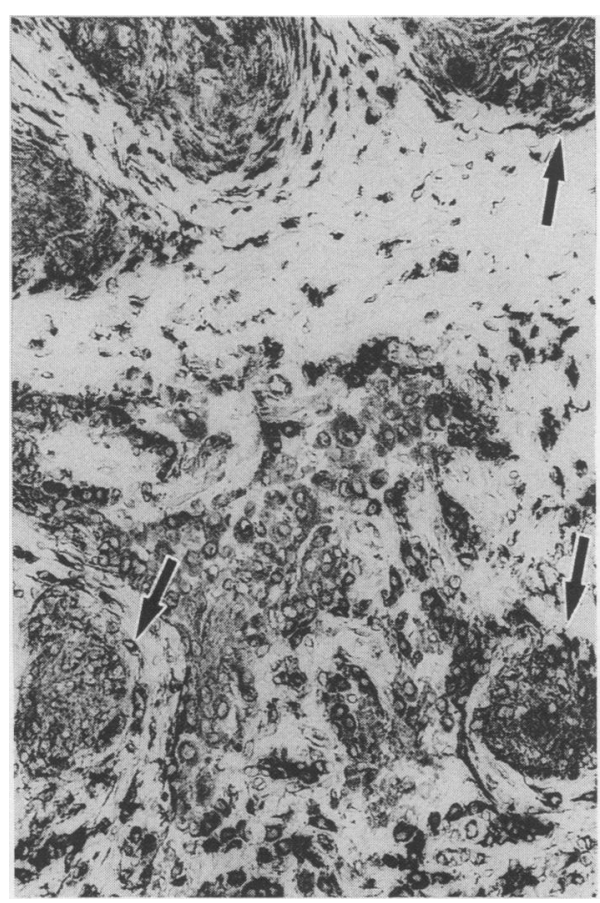

Fig 6 Strongly positive staining of alveolar epithelium to $H L A-D R$ in patient with sarcoidosis (Immunoperoxidase technique.) Strongly positive granulomas can be seen (arrows).

also comprise a humoral effector phase.

To analyse the specificity of our findings in IPF we studied biopsy specimens from patients with sarcoidosis and infection. Sarcoidosis, a multisystem disorder of unknown aetiology, is characterised by an active cellular immune response, ${ }^{1}$ the target of which is unknown. Immunocytochemically, T4 positive (helper/inducer) cells predominate both in the lavage fluid and in the interstitium. ${ }^{16}$ Although spontaneous
Table 5 Immunohistological findings in lung biopsy specimens of four patients with sarcoidosis

\begin{tabular}{|c|c|c|c|c|}
\hline & \multicolumn{4}{|c|}{ Case No } \\
\hline & 10 & 11 & 12 & 13 \\
\hline $\begin{array}{l}\text { Mononuclear cell infiltration } \\
\text { Granulomas }\end{array}$ & $\stackrel{+}{+}$ & $\begin{array}{l}++ \\
+\end{array}$ & $\begin{array}{l}+++ \\
+++\end{array}$ & $\begin{array}{l}++ \\
+++\end{array}$ \\
\hline Langhans' giant cells & - & - & +++ & + \\
\hline Interstitial fibrosis & - & -- & + & + \\
\hline \multirow{4}{*}{$\begin{array}{l}\text { Ia staining of bronchial } \\
\text { epithelium } \\
\text { Ia staining of alveolar } \\
\text { epithelium } \\
\text { Leu } 10 \text { (DS) staining of } \\
\text { bronchial epithelium } \\
\text { Leu } 10 \text { (DS) staining of } \\
\text { alveolar epithelium }\end{array}$} & ++ & ++ & + & \\
\hline & + & - & + & ++ \\
\hline & + & - & - & ND \\
\hline & - & - & - & ND \\
\hline $\begin{array}{l}\text { T4 positive lymphocytes } \\
\text { T8 positive lymphocytes } \\
\text { Bl positive lymphocytes }\end{array}$ & $\begin{array}{l}+ \\
+ \\
-\end{array}$ & $\begin{array}{l}+ \\
+ \\
+\end{array}$ & $\begin{array}{l}++ \\
++ \\
+\end{array}$ & $\begin{array}{l}\text { ND } \\
\text { ND } \\
\text { ND }\end{array}$ \\
\hline
\end{tabular}

ND $=$ not done.

fluctuations occur in many cases, the disease may pass into a chronic state, resulting in extensive fibrosis. In such cases mechanisms similar to autoantigen presentation may be operative as in IPF. Indeed, we found class II expression on the alveolar epithelium in three cases of sarcoidosis. All these patients had active disease at the time of the biopsy; but none of them developed extensive fibrosis during an observation of several years, despite the fact that two of them were not treated with corticosteroids. Apparently, class II expression on the alveolar epithelium does not necessarily result in fibrosis in sarcoidosis.

Class II expression was also observed on the alveolar epithelium in patients with interstitial lung disease caused by infection with viruses or mycobacteria. Histologically, the infiltrate consisted predominantly of lymphocytes of the T4 phenotype (helper/inducer)

Table 6 Immunohistological findings in lung biopsy specimens of six patients with presumably infectious diseases

\begin{tabular}{|c|c|c|c|c|c|c|}
\hline & \multicolumn{6}{|c|}{ Case No } \\
\hline & 14 & 15 & 16 & 17 & 18 & 19 \\
\hline $\begin{array}{l}\text { Mononuclear cell infiltration } \\
\text { Plasmacellular infiltration } \\
\text { Cuboid metaplasia of alveolar epithelium } \\
\text { Fibrosis } \\
\text { Polymorphonuclear cell infiltration }\end{array}$ & $\begin{array}{l}++ \\
+ \\
++ \\
-\end{array}$ & $\begin{array}{l}+ \\
++ \\
++ \\
-\end{array}$ & $\begin{array}{l}+++ \\
++ \\
+ \\
-\end{array}$ & $\begin{array}{l}+++ \\
\bar{t}+ \\
\bar{t}\end{array}$ & $\begin{array}{l}++ \\
++ \\
++ \\
\pm \\
+\end{array}$ & $\begin{array}{l}++ \\
+ \\
+ \\
\pm \\
+\end{array}$ \\
\hline $\begin{array}{l}\text { Ia staining of bronchial epithelium } \\
\text { Ia staining of alveolar epithelium }\end{array}$ & $\begin{array}{l}++ \\
++\end{array}$ & $\begin{array}{l}++ \\
++\end{array}$ & $\begin{array}{l}+ \\
+\end{array}$ & $\begin{array}{l}++ \\
++\end{array}$ & $\begin{array}{l}++ \\
+\end{array}$ & $\begin{array}{l}+ \\
+\end{array}$ \\
\hline $\begin{array}{l}\text { T4 positive lymphocytes } \\
\text { T8 positive lymphocytes } \\
\text { Bl positive lymphocytes }\end{array}$ & $\begin{array}{l}++ \\
+ \\
\text { ND }\end{array}$ & $\begin{array}{l}+ \\
+ \\
\text { ND }\end{array}$ & $\begin{array}{l}+t \\
++ \\
-\end{array}$ & $\begin{array}{l}++ \\
++ \\
\text { ND }\end{array}$ & $\begin{array}{l}++ \\
+ \\
+\end{array}$ & $\begin{array}{l}++ \\
++ \\
\text { ND }\end{array}$ \\
\hline
\end{tabular}

ND, not done. 
Fig 7 Negative HLA-DR expression on alveolar epithelium of patient with bacterial pneumonia. Scattered positive alveolar macrophages can be seen.

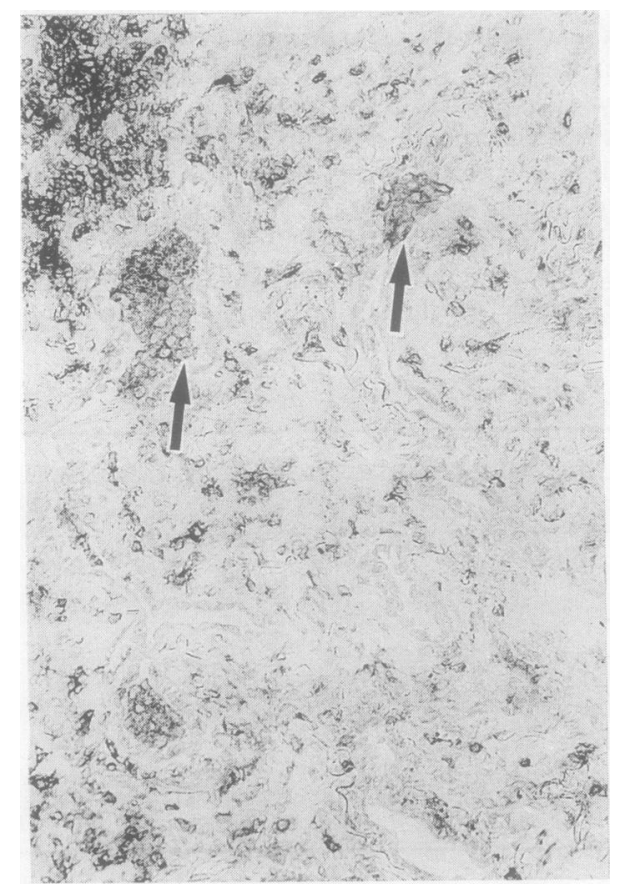

Fig 8 Clusters of T4 positive lymphocltes with immunoperoxidase staining in lung biopsy specimen from patient with IPF. Note weak staining of alveolar macrophages (arrow).

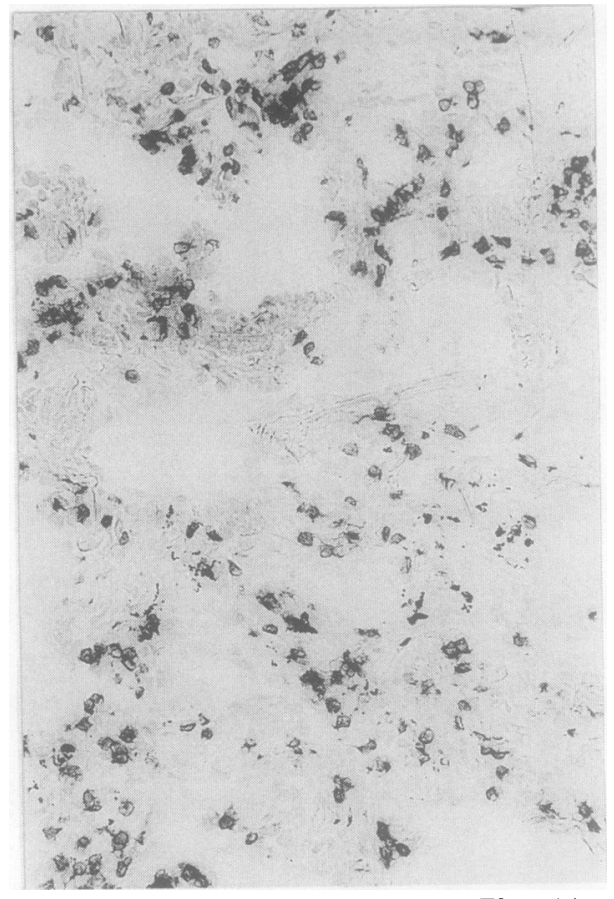

Fig 9 Immunoperoxidase staining showing T8 positive lymphocytes scattered through interstitium. T8 lymphocytes were also often seen in alveoli and between or adjacent to epithelial cells.

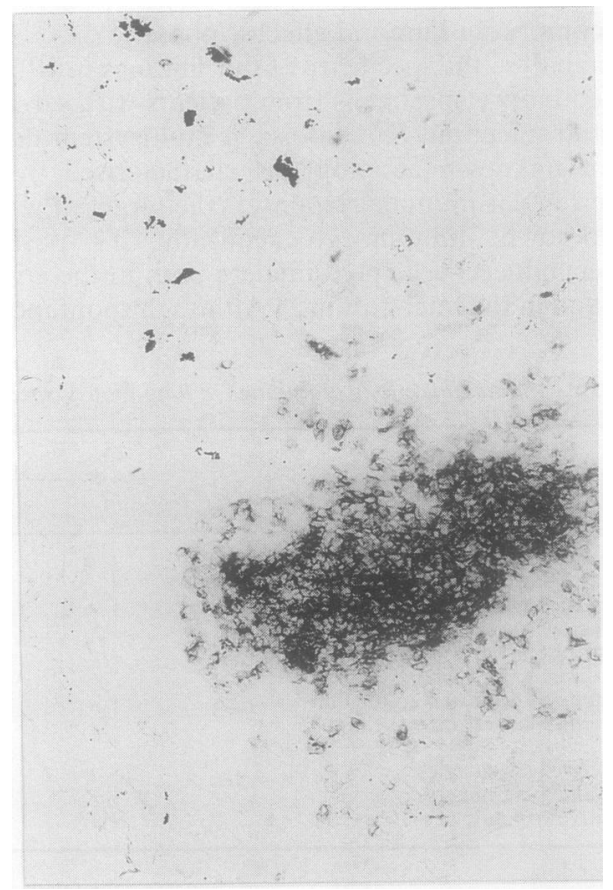

Fig 10 Immunoperoxidase staining showing follicular arrangement of $B 1$ positive lymphocltes in patient with 
and plasma cells, reflecting an active immune response against mycobacterial and viral antigens. Apparently, this local immune response results in the expression of class II antigens on epithelial cells, probably as a result of the local production of $\gamma$-interferon (IFN- $\gamma$ ) during a viral infection. ${ }^{17} 18$ Expression of class II antigens on renal epithelial cells has been shown during cytomegalovirus infection in recipients of renal allografts, and has been considered to enhance graft rejection. ${ }^{19}$ We did not observe chronic interstitial lung disease in patients recovering from viral pneumonias (data not shown), but class II expression on alveolar epithelium, caused by viral infection in patients with allogeneic bone marrow transplantation, may be related to progressive interstitial lung disease, which develops in a substantial number of these patients. In contrast, class II antigens were not expressed by the alveolar epithelium of patients with bacterial pneumonias. In these patients the infiltrate consisted of polymorphonuclear leucocytes that probably do not produce IFN- $\gamma$.

The mechanism underlying the expression of class II antigens on alveolar epithelium is not fully understood. There is increasing evidence, however, that IFN- $\gamma$ induces class II expression on epithelial cells. ${ }^{20}$ Viral infection, in vivo and in vitro, induces release of interferon from mononuclear cells. ${ }^{1718}$ Interestingly, spontaneous release of IFN- $\gamma$ has been shown in sarcoidosis by alveolar macrophages and lung $\mathrm{T}$ lymphocytes, ${ }^{21}$ whereas normal lung mononuclear cells produce little or no IFN- $\gamma$. In IPF class II expression on the alveolar epithelium is probably also a result of local IFN- $\gamma$ production by activated T cells. Class II expression on epithelia during cellular immune responses of non-infectious origin has also been shown for keratinocytes in several skin disorders. ${ }^{22}$ These studies suggest that class II expression on the alveolar epithelium is probably a result of local production of IFN- $\gamma$ by activated $T$ cells. Although induction of class II expression on the alveoli is not restricted to IPF, it may still be relevant in the pathogenesis of IPF-by facilitating the induction of an autoimmune response.

\section{References}

1 Crystal RG, Bitterman PB, Rennard SI, Hance AJ, Keogh BA. Interstitial lung disease of unknown etiology: disorders characterized by chronic inflammation of the lower respiratory tract. $N$ Engl J Med 1984;310:154-66, 235-44.

2 Turner-Warwick M, Haslam P. Antibodies in some chronic fibrosing lung disease. I. Non organ-specific autoantibodies. Clin Allergy 1971;1:83-95.

3 Chapman JR, Charles PJ, Venables PJW, et al. Definition and clinical relevance of antibodies to $n$-ribonucleoprotein and other nuclear antigens in patients with cryptogenic fibrosing alveolitis. Am Rev Respir Dis 1984;130:439-43.
4 Hanafusa T, Pujol-Borrell R, Chiovato L, Russell RCG, Doniach D, Bottazzo GF. Aberrant expression of HLA-DR antigens on thyrocytes in Graves' disease: relevance for autoimmunity. Lancet 1983;ii:1111-5.

5 Ballardini G, Mirakian R, Bianchi FB, Pisi E, Doniach D, Bottazzo GF. Aberrant expression of HLA-DR antigens on bileduct epithelium in primary biliary cirrhosis: relevance to pathogenesis. Lancet 1984;ii:1009-13.

6 Bottazzo GF, Dean BM. Evidence for the expression of class II (HLA-DR) and increased presentation of class I (HLA-A,B,C) molecules in pancreatic islets in type $I$ (insulin dependent) diabetes. Diabetologica 1984;27:259A.

7 Bottazzo GF, Pujol-Borrell R, Hanafusa T, Feldmann M. Role of aberrant HLA-DR expression and antigen presentation in induction of endocrine autoimmunity. Lancet 1983;ii:1115-9.

8 Londei M, Lamb JR, Bottazzo GF, Feldmann M. Epithelial cells expressing aberrant MHC class II determinants can present antigen to cloned human T-cells. Nature 1984;312:639-41.

9 Gahring L, Baltz M, Pepys MB, Daynes R. Effect of ultraviolet radiation on production of epidermal cell thymocyte-activating factor/interleukin 1 in vivo and in vitro. Proc Natl Acad Sci USA 1984;81:1198-202.

10 Kallenberg CGM, Schilizzi BS, Beaumont F, Poppema S, de Leij L, The TH. Expression of class II MHC antigens on alveolar epithelium in fibrosing alveolitis. Clin Exp Immunol 1987;67:182-90.

11 Poppema S, Bhan AK, Reinherz EL, McCluskey RT, Schlossmann ST. Distribution of $T$ cell subsets in human lymph nodes. J Exp Med 1981;153:30-41.

12 Stashenko P, Nadler LM, Hardy R, Schlossmann SF. Characterisation of a human B lymphocyte-specific antigen. $J$ Immunol 1980;125:1678-85.

13 Ward MJ, Davies D. Riedel's thyroiditis with invasion of the lungs. Thorax 1981;36:956-7.

14 Weissman E, Becker NH. Interstitial lung disease in primary biliary cirrhosis. Am J Med Sci 1983;285:21-7.

15 Campbell DA, Poulter LW, Janossy G, du Bois RM. Immunohistological analysis of lung tissue from patient with cryptogenic fibrosing alveolitis suggesting local expression of immune hypersensitivity. Thorax 1985;40:405-11.

16 Hunninghake GW, Crystal RG. Pulmonary sarcoidosis: a disorder mediated by excess helper T-lymphocyte activity at sites of disease activity. $N$ Engl J Med 1981;305:429-34.

17 Cunningham AL, Merigan TC. $\gamma$-interferon production appears to predict time of recurrence of herpes labialis. J Immunol 1983;130:2397-400.

18 Neumann C. Mononuclear phagocytes as producers of interferon. In: Pick E, ed. Lymphokines. Vol 7. New York: Academic Press, 1982:165-201.

19 Willebrand von E, Pettersson E, Ahonen J, Hayry P. Cytomegalovirus infection, class II expression and rejection during the course of cytomegalovirus disease. Transpl Proc 1986;18:32-4.

20 Todd I, Pujol-Borrell R, Hammond IJ, Bottazzo GF, Feldmann $M$. Interferon- $\gamma$ induced HLA-DR expression in thyroid epithelium. Clin Exp Immunol 1985;61:265-73.

21 Robinson BWS, McLemore ThL, Crystal RG. Gamma interferon is spontaneously released by alveolar macrophages and lung $\mathrm{T}$ lymphocytes in patients with pulmonary sarcoidosis. $J$ Clin Invest 1985;75:1488-95.

22 Lampert IA. Expression of HLA-DR (Ia-like) antigen on epidermal keratinocytes in human dermatoses. Clin Exp Immunol 1984;57:93-100.

Requests for reprints to: Dr CGM Kallenberg, Department of Clinical Immunology, University Hospital, Oostersingel 59, 9713 EZ Groningen, The Netherlands. 